${ }^{1}$ Dept. of Animal Science, The Pennsylvania State University, University Park, PA 16802, USA

'Dept. of Food Science, The Pennsylvania State University, University Park, PA 16802, USA

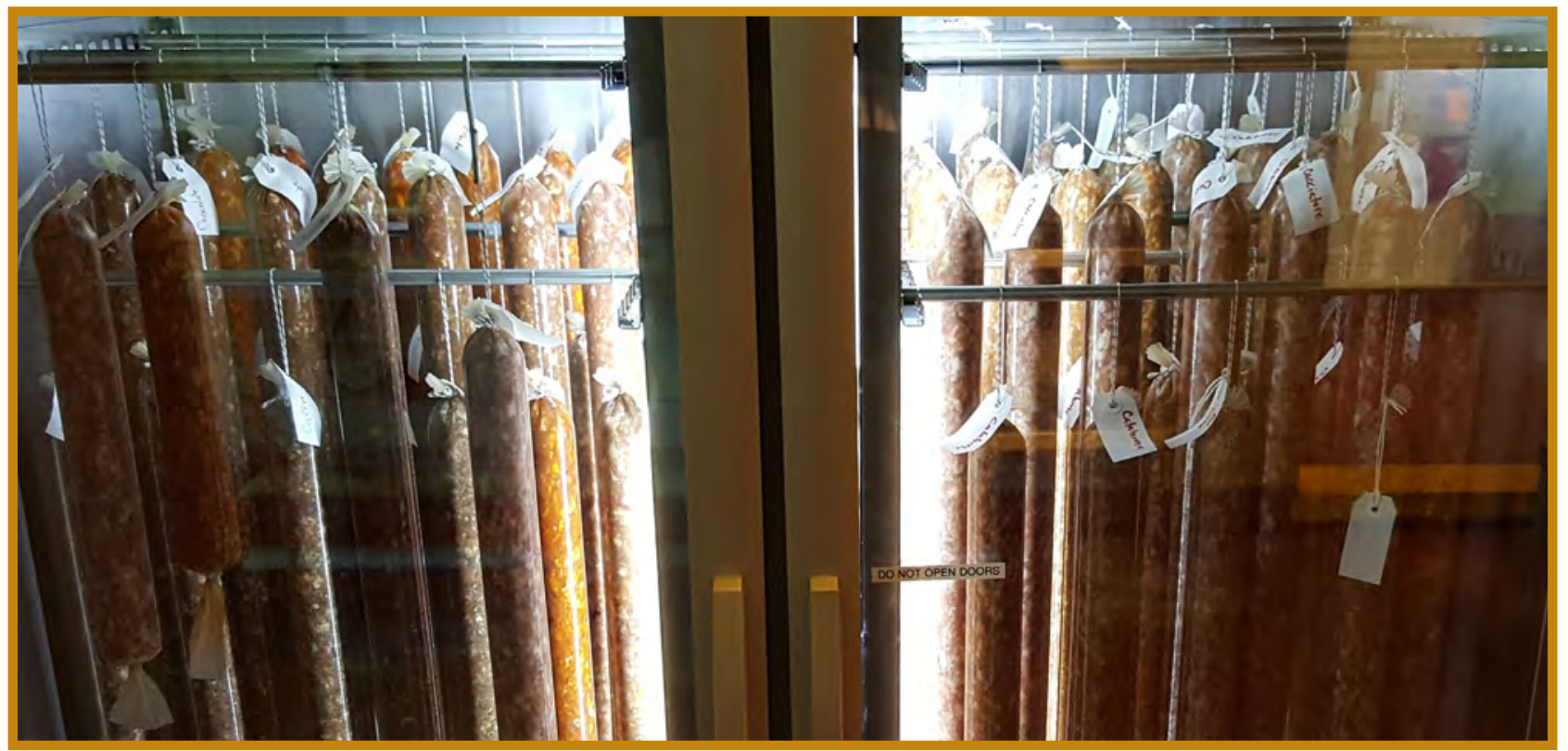

\title{
Fate of Salmonella spp., Listeria monocytogenes, and Campylobacter spp. During Fermentation and Drying of Duck Salami
}

\section{ABSTRAGT}

Creating artisanal dry salami products is an increasing trend for charcuterie companies in the United States. These products are required by the U.S. Department of Agriculture Food Safety and Inspection Service to have a scientifically valid hazard analysis critical control point system addressing relevant biological hazards. The objective of this study was to determine if a manufacturing process could achieve a 5-log reduction of Salmonella spp., Listeria monocytogenes, and Campylobacter spp. for duck salami. Duck trim and pork belly were experimentally inoculated, tumbled with 2.5\% Beefxide, ground, and mixed with salt (2.5\%), cure ( $\mathrm{NaNO}_{3}$ and $\mathrm{NaNO}_{2}$ ), spices, and starter culture. The batter was stuffed into collagen casings (55 mm), fermented $\left(23^{\circ} \mathrm{C}\right.$ and $95 \%$ relative humidity), and dried $\left(12^{\circ} \mathrm{C}\right.$ and $75 \%$ relative humidity) to $44 \%$ weight loss. Salamis were vacuum packaged and stored at $23^{\circ} \mathrm{C}$ (approximately 4 weeks). Pathogen concentrations, $\mathrm{pH}$, and water activity were analyzed throughout production. Final reductions of 7.03 , 5.90, and 7.19 log were achieved for Salmonella spp.,
L. monocytogenes, and Campylobacter spp., respectively. A final $\mathrm{pH}$ of 5.11 and final water activity of 0.81 were also achieved. The results of this study indicate that the parameters used to ferment and dry duck salami are able to achieve a 5-log reduction of each pathogen and, thus, validate the safe production of the product.

\section{INTRODUCTION}

Traditional salamis, like Genoa and cacciatore, are produced by mixing ground pork with salt, cure, spices, and a lactic acid-producing starter culture. The salamis are fermented to produce traditional flavors, as well as to allow for acid coagulation of proteins by slowly decreasing the $\mathrm{pH}$ of the meat. Following fermentation, salamis are typically dried to remove moisture and decrease the water activity $\left(\mathrm{a}_{\mathrm{w}}\right)$ of the product. Traditionally produced salamis often do not undergo a thermal processing step and are sold as raw, readyto-eat (RTE) products $(8,20,29)$.

Producing fermented and dried salamis with duck meat as the primary ingredient is a departure from traditional salami production methods. However, the popularity of processed 
poultry products is increasing in the United States, due in part to the perception that poultry is healthier than beef or pork. Charcuterie companies in the United States have been able to successfully market processed poultry products that include salami (3). The use of duck in a salami presents some unique quality challenges. The main challenge is that traditional salami relies heavily on the presence of up to $50 \%$ fat in the finished product for flavor and other sensory characteristics. Since poultry fat is at a higher risk for lipid oxidation than is pork or beef fat, this addition may present some undesirable quality traits. Poultry fat contains a high percentage of unsaturated fats that are more susceptible to oxidation than the saturated fats that make up the majority of beef and pork adipose tissue (3). Manufacturers that do not wish to add antioxidants to a salami can prevent the oxidation of poultry fat in a salami by removing as much fat as possible from the raw duck meat prior to production and then use another source of fat, like pork, that does not oxidize as readily.

Raw, RTE duck salami also faces unique microbial safety challenges. To prevent the survival and growth of pathogens, duck salami relies on multiple antimicrobial parameters inherent to the product and process, which are called "hurdles" (26). Reducing $\mathrm{pH}$ by fermentation, reducing aw by drying, increasing osmotic stress by adding salt, and adding spices that have antimicrobial properties are steps traditionally used in combination to ensure the safety of salami products. The combined effect of each hurdle (hurdle effect) creates an unfavorable environment for pathogenic cells that may be present and can, over time, cause cell death due to the use of all available energy substrates $(23,25,26)$. The hurdle effect is a widely used method to improve the microbial safety of food products, and using multiple hurdles in combination creates two practical implications for meat processors. First, the collective use of multiple hurdles allows the strength and severity of each individual hurdle to be lessened without compromising the safety of the product $(4,27)$. For example, because salami is dried, the $\mathrm{pH}$ of the final product can be held at more palatable levels than in a meat product that is not dried as much. Second, the use of all of the hurdles mentioned above allows meat processors to produce safe products that do not undergo a thermal treatment. Thermal treatments are effective methods for reducing the presence of pathogens in a meat product (4), but traditional salami products are not thermally processed to maintain flavor and texture qualities that consumers expect. Recently, the use of organic acid treatments on raw meat, prior to salami production, has been acceptable as an additional hurdle. Beefxide (Birko Corporation, Henderson, $\mathrm{CO}$ ), which is approved as a processing aid in meat products by the U.S. Department of Agriculture (USDA), is commonly used for treatment of raw meat prior to grinding. When used properly, the hurdle effect will ensure that traditional salami is both safe to eat and meets the highest standards for quality.
Salmonella spp. and Campylobacter spp. are both commonly found in live poultry and raw poultry meat ( 1 , $5,9,10,24,28,30,32,34,42,43)$, and multiple foodborne illness outbreaks have been attributed to both pathogens in poultry $(8,9)$. The U.S. Centers for Disease Control and Prevention (CDC) have reported 760 foodborne illness outbreaks due to Salmonella spp. associated with poultry between 2000 and 2017. The outbreaks caused over 10,000 reported illnesses, over 1,700 reported hospitalizations, and 27 deaths (7). The CDC has reported fewer confirmed outbreaks of Campylobacter spp. than of Salmonella spp. The 478 outbreaks of Campylobacter spp. due to food have caused roughly 8,000 reported illnesses, 367 hospitalizations, and one death (7). It was determined that meat and poultry products were implicated in 100 of the outbreaks, and roughly 1,000 of the illnesses were confirmed to be linked to meat and poultry products (7).

Listeria monocytogenes is a pathogen of concern for RTE meat products because of its ability to grow at refrigeration temperatures and colonize meat processing environments $(2,6,11,13,14-19,22,44)$. From 2000 to 2017 , there were five outbreaks of $L$. monocytogenes associated with meat, resulting in 101 confirmed illnesses, 47 hospitalizations, and 16 deaths. Of these five outbreaks, three were confirmed to be caused by poultry deli meats $(7,10)$. Additionally, there was one confirmed outbreak related to duck charcuterie products in Australia. Seven people were hospitalized due to salmonellosis when a duck prosciutto was improperly prepared at a restaurant (12).

To combat the presence and survival of these pathogens in meat products, the USDA Food Safety and Inspection Service (FSIS) requires that pathogens of concern be addressed by meat and poultry processors using scientifically valid preventative methods via a hazard analysis critical control point (HACCP) system (40). Challenge studies performed in a research laboratory are a method commonly utilized by meat processors for assistance in documenting the safety of a specific product or technology that addresses specific hazards. These studies utilize pathogens of concern for a specific product to demonstrate the safety of that product. During a challenge study, the processing parameters decided upon by the meat processor are utilized by researchers to determine if those parameters can achieve adequate reductions of the pathogens inoculated. Salmonella spp., L. monocytogenes, and Campylobacter spp. are the pathogens most likely to be addressed when considering the safety of an RTE duck salami (1, 5, 10, 15, 18, 19, 21, 22, 24, $30,32)$. Although a $7 \log \mathrm{CFU} / \mathrm{g}$ reduction of Salmonella spp. is recommended to demonstrate that no viable Salmonella spp. cells are present in the final product, a $5 \log \mathrm{CFU} / \mathrm{g}$ reduction of the pathogen is used as a measure of validity for a "safe" process (39). L. monocytogenes is considered by USDA-FSIS to be an adulterant in RTE products for human consumption, and its presence in RTE meat 
products is illegal. To demonstrate that L. monocytogenes is not present in a RTE product, meat processors must demonstrate that L. monocytogenes cells are not able to grow at any point throughout the shelf life of the product (41). Lastly, the USDA-FSIS requires that Campylobacter spp. be addressed in HACCP documentation for meat products containing poultry and that a 5-log CFU reduction of Campylobacter spp. be achieved in RTE poultry products (40). To demonstrate those reductions in a duck salami, an experiment was designed to validate the bacterial safety of a process used to manufacture a fermented and dried duck salami, utilizing Salmonella spp., L. monocytogenes, and Campylobacter spp. as pathogens of concern.

\section{MATERIALS AND METHODS}

\section{Culture selection and growth}

The following cultures were received or purchased from American Type Culture Collection (ATCC; Manassas, VA), CDC, or USDA: Salmonella enterica subsp. enterica serovar Typhimurium (ATCC 14028, isolated from chicken organs), S. enterica subsp. enterica serovar Montevideo isolate SMvo13 (CDC), S. enterica subsp. enterica serovar Derby (ATCC 7378, human isolate), L. monocytogenes strain Scott A, L. monocytogenes serotype $1 / 2$ a isolate FSL R2-603 (deli meats outbreak), L. monocytogenes serotype 4b isolate H3396 (hot dog outbreak), Campylobacter jejuni isolate PSU99 (isolated from chicken in Pennsylvania, species confirmed by USDAAgricultural Research Service), C. jejuni (ATCC 29428, human isolate), and Campylobacter coli (ATCC 33559, pig isolate). These cultures were chosen for their role in human illness or association with meat and food products.

Overnight cultures of each Salmonella serovar and $L$. monocytogenes strain were grown from laboratory stocks by adding a loopful of culture to $10 \mathrm{~mL}$ of tryptic soy broth (TSB; BD, Sparks, MD) and incubating for $24 \mathrm{~h}$ at $37^{\circ} \mathrm{C}$ under aerobic conditions. To ensure working stocks were not contaminated, the following procedure was used. Each bacterium was streaked for isolation from the overnight culture on selective media. Xylose lysine deoxycholate agar (BD) was used for Salmonella spp., and modified Oxford agar (BD) was used for L. monocytogenes. Salmonella species and Listeria latex confirmation tests were performed using an isolated colony for each strain of bacteria (Microgen Bioproducts, Camberley, UK). A single colony of each Salmonella serovar and L. monocytogenes strain was added to $10 \mathrm{~mL}$ of fresh TSB (BD) and incubated under the same conditions to achieve a concentration of approximately $8 \log$ $\mathrm{CFU} / \mathrm{ml}$.

Campylobacter spp. cultures were grown from agar slants received from ATCC or the USDA Agricultural Research Service. A loopful of culture for each strain was inoculated into $10 \mathrm{~mL}$ of Brucella broth (Hi Media Laboratories, Mumbai, India) and grown for $48 \mathrm{~h}$ at $37^{\circ} \mathrm{C}$ under microaerophilic conditions $\left(10 \% \mathrm{CO}_{2}\right.$ and $\left.90 \% \mathrm{~N}_{2}\right)$. Strains were streaked for isolation on charcoal cefoperazone deoxycholate agar (CCDA; Oxoid Ltd., Basingstoke, England) and incubated for $48 \mathrm{~h}$ under the same conditions. Campylobacter spp. latex confirmation tests (Microgen Bioproducts) were performed for each strain using an isolated colony. An isolated colony was also inoculated into $10 \mathrm{~mL}$ of fresh Brucella broth (Hi Media Laboratories) for $48 \mathrm{~h}$ under the same conditions to achieve an approximate concentration of $8 \log \mathrm{CFU} / \mathrm{ml}$.

An inoculation bath was created for the inoculation of raw duck and pork belly. Fresh $10-\mathrm{mL}$ overnight cultures of each of the nine strains of Salmonella spp., L. monocytogenes, and Campylobacter spp. were incubated in either TSB (BD) or Brucella broth (Hi Media Laboratories). The overnight cultures were then added to a fresh $340-\mathrm{mL}$ amount of either TSB (BD) or Brucella broth (Hi Media Laboratories) and incubated again for the same length of time. After incubation, the $350-\mathrm{mL}$ broth cultures were centrifuged for $5 \mathrm{~min}$ at $21^{\circ} \mathrm{C}$ at approximately $11,000 \times \mathrm{g}$ (Avanti J-26 CPI; Beckman Coulter, Inc., Pasadena, CA). After centrifugation, the supernatant was decanted and disposed of, and the cultures were resuspended in $1 \times$ phosphate buffered saline (Alfa Aesar, Tewksbury, MA). The resuspended cultures of all nine strains were combined in a sterilized metal bin to make an inoculation bath approximating $3.2 \mathrm{~L}$.

\section{Duck salami production}

Duck trim, pork belly, seasonings, and casings were provided separately for each of the three independent replications by a salami company in the northeastern United States. For a single replication, duck trim and pork belly were thawed upon arrival $\left(4^{\circ} \mathrm{C}\right)$, cut into pieces of approximately $5 \mathrm{~cm}^{3}$, and weighed into a $13.6-\mathrm{kg}$ meat block containing $70 \%$ duck and $30 \%$ pork belly. On the first day of production, the duck trim and pork belly pieces were submerged in the inoculation bath for $30 \mathrm{~min}$ in a biological safety cabinet, with stirring every $5 \mathrm{~min}$, so that the pathogens could attach to the meat surfaces. After $30 \mathrm{~min}$ of submersion in the inoculation bath, the meat was scooped onto a draining cart and allowed to remain undisturbed for $30 \mathrm{~min}$ in the biological safety cabinet. After drying, the meat was transferred to a clean plastic container, treated with $1 \mathrm{~L}$ of $2.5 \%$ Beefxide solution (Birko Corp.) that contained a proprietary blend of lactic acid, citric acid, and potassium hydroxide, and manually tumbled with a large, sterile spoon for $15 \mathrm{~min}$. When tumbling was completed, the meat was moved to a different clean plastic container and placed into a walk-in cooler $\left(4^{\circ} \mathrm{C}\right)$ overnight. Approximately $24 \mathrm{~h}$ after tumbling, the duck and pork meat was ground once through a 6-mm grinding plate using a size 22 grinder (Avantco Equipment MG22, Clark Associates, Inc., Lancaster, PA) and then mixed with salt $(2.5 \%$; w/w) $0.24 \%$ cure \#2 ( $92.75 \%$ salt, $6.25 \%$ sodium nitrite [ $150 \mathrm{ppm}$ in-going], $1 \%$ sodium nitrate $[24 \mathrm{ppm}$ in-going], and dextrose [0.5\%; $\mathrm{w} / \mathrm{w}])$, coriander $(0.35 \% ; \mathrm{w} / \mathrm{w})$, garlic $(0.2 \%$; w/w), black 
pepper $(0.15 \% ; \mathrm{w} / \mathrm{w})$, ground white pepper $(0.15 \% ; \mathrm{w} / \mathrm{w})$, ground nutmeg $(0.13 \%)$, and freeze-dried starter culture (Bactoferm F-LC; Chr. Hansen A/S, Hørsholm, Denmark) that was reconstituted in approximately $20 \mathrm{~mL}$ of distilled water. Following mixing, the salami batter was hand stuffed (10 lb. Sausage Stuffer; The Sausage Maker, Inc., Buffalo, $\mathrm{NY}$ ) into 55-mm collagen casings (Globe Packaging, Inc., Carlstadt, NJ) and hand tied using butcher twine. Each casing contained four salamis that were each approximately 260 grams in weight. A single salami in a separate casing was used as a reference to measure weight loss and diameter changes during the fermentation and drying process. A total of 48 salamis were produced for each of the three replications $(n=144)$. After stuffing, the salamis were hung in the drying cabinet (AS50, Impianti Condizionamento Salumifici, Camposanto, Modena, Italy) and fermented for $48 \mathrm{~h}$ at $23^{\circ} \mathrm{C}$ and $95 \%$ relative humidity $( \pm 5 \%)$. Following fermentation, the salamis were dried at $14^{\circ} \mathrm{C}$ and $75 \%$ relative humidity to a target weight loss of $44 \%$. Drying averaged 5 weeks among three replications. When salamis completed drying, they were individually vacuum packaged (Ultravac UV 250, Koch Packaging, Kansas City, MO) in 3-mil food-grade pouches (oxygen transmission rate of 50 to $70 \mathrm{cc} / \mathrm{m} 2 / 24 \mathrm{~h}$; UltraSource LLC, Kansas City, MO) and stored at $\sim 23^{\circ} \mathrm{C}$ for an additional 4 weeks. The $\mathrm{pH}$ and $\mathrm{a}_{\mathrm{w}}$ targets for the final product were less than 5.3 and less than 0.90 , respectively.

\section{Sampling procedures}

For each replication, samples were taken on days 0 , $1,2,3,5$, and 10 and then every 7 days until day 66 . On each sampling day, three random salamis were taken for enumeration of pathogens and one salami sample was taken for determination of $\mathrm{pH}$ and $\mathrm{a}_{\mathrm{w}}$. On days 0 and 1 , excised surface samples $(25 \mathrm{~g})$ were taken aseptically from duck trim and pork belly surfaces, prior to salami production. For enumeration of pathogens in the final product, salamis were cut in half, and the cores of each half were removed using a sterile plastic spoon. Twenty-five grams of meat was homogenized (Seward Stomacher 400 Circulator, Fermionx Ltd., Worthing, West Sussex, UK) with 100 grams of buffered peptone water (BD) for $1 \mathrm{~min}$ at $260 \mathrm{rpm}$, and then the stomachate was serially diluted using $9 \mathrm{~mL}$ of buffered peptone water (BD) blanks. Excised surface samples from duck and pork belly were homogenized with $100 \mathrm{ml}$ of buffered peptone water, stomached, and serially diluted as described above. Each sample was plated onto xylose lysine deoxycholate agar (BD), modified Oxford agar (BD), CCDA (Oxoid), and tryptic soy agar (TSA; BD) plates in duplicate at the relevant dilutions and incubated using the methods stated above. Resulting colonies were counted and averaged, and the counts converted to log CFU/g. Colonies matching the morphologies of Salmonella spp., L. monocytogenes, and Campylobacter spp. were confirmed using latex agglutination (Microgen Bioproducts) on each sampling day. Enrichment procedures were conducted according to the methods of McKinney et al. (31) for Salmonella spp. and L. monocytogenes and were adapted for Campylobacter spp. by using Brucella broth (Hi Media Laboratories) and CCDA (Oxoid) and incubating using the parameters stated above. $\mathrm{pH}$ was measured from the surface of either duck or pork belly pieces on day 0 and day 1 (A57184 $\mathrm{pH}$ electrode, Beckman Coulter, Inc.) or from the center of a salami for the remaining samples (Testo $206 \mathrm{pH} 2$, Testo North America, West Chester, PA). Two $\mathrm{pH}$ measurements were taken on each sampling day, one from each half of the fourth sample salami. aw samples were measured from a slice taken from the core of the salami (Aqualab 4TE, Meter Group, Inc., Pullman, WA). Only one aw measurement was taken on each sampling day.

\section{Statistical analysis}

Resulting populations of Salmonella spp., L. monocytogenes, and Campylobacter spp. were analyzed independently using the general linear model with unique comparisons $(\alpha=0.05)$ (SAS 9.4, SAS Institute, Inc., Cary, NC). The detection limit was calculated as 0.38 using a dilution factor of 5 and $0.5 \mathrm{CFU} / \mathrm{g}$. In order to preserve statistical power, statistical comparisons were made between the average pathogen concentration from one sampling day and the concentration of the same pathogen on the following sampling day. Statistical analysis was not utilized for $\mathrm{a}_{\mathrm{w}}$ and $\mathrm{pH}$ data.

\section{RESULTS}

Fermentation, drying, and vacuum-packaged storage were able to achieve $>5 \log \mathrm{CFU} / \mathrm{g}$ reductions on average in Salmonella spp. $(n=9, P<0.0001)$, L. monocytogenes $(n=9, P<0.0001)$, and Campylobacter spp. $(n=9, P<$ 0.0001 ) (Table 1). Salmonella spp. achieved an average 5.47 $\log \mathrm{CFU} / \mathrm{g}$ reduction on day 38 of processing, followed by a final average reduction of $7.03 \mathrm{log} \mathrm{CFU} / \mathrm{g}$ on day 66. L. monocytogenes achieved an average $5.20 \log \mathrm{CFU} / \mathrm{g}$ reduction on day 59 of processing, with a final average reduction of $5.90 \log \mathrm{CFU} /$ g. Campylobacter spp. achieved an average 6.85 $\log \mathrm{CFU} / \mathrm{g}$ reduction on day 45 of processing, with a final average reduction of $7.19 \log \mathrm{CFU} / \mathrm{g}$. The average reductions in Salmonella spp., L. monocytogenes, and Campylobacter spp. that occurred after Beefxide treatment of $0.26 \log \mathrm{CFU} / \mathrm{g}$, $0.29 \log \mathrm{CFU} / \mathrm{g}$, and $0.20 \log \mathrm{CFU} / \mathrm{g}$, respectively, were not significant. Pathogen concentrations did not increase by more than $1 \log \mathrm{CFU} / \mathrm{g}$ at any point during the experiment, indicating that pathogens did not grow during the production of duck salami. The concentration of bacteria on TSA (BD), which was presumed to be starter culture, remained greater than $5 \log \mathrm{CFU} / \mathrm{g}$ on day 66 . Enrichments were conducted when pathogen concentrations reached levels below the detection limit ( $0.39 \log \mathrm{CFU} / \mathrm{g}$ ) of the plating assay ( $n$ $=9$ ). By day 59, all samples produced negative Salmonella spp. enrichment results. L. monocytogenes produced positive 
TABLE 1. Pathogen concentrations (log GFU/g \pm standard error) of Salmonella spp.,

L. monocytogenes, and Campylobacter spp. $(\boldsymbol{n}=9)$ in duck salami during sampling

\begin{tabular}{|c|c|c|c|c|c|c|c|}
\hline $\begin{array}{l}\text { Processing } \\
\text { step }\end{array}$ & Day & Salmonella spp. & $\begin{array}{l}\text { Salmonella spp. } \\
\text { reduction }\end{array}$ & L. monocytogenes & $\begin{array}{l}\text { L. monocytogenes } \\
\text { reduction }\end{array}$ & $\begin{array}{l}\text { Campylobacter } \\
\text { spp. }\end{array}$ & $\begin{array}{l}\text { Campylobacter } \\
\text { spp. reduction }\end{array}$ \\
\hline Inoculation & 0 & $7.41 \pm 0.04^{\mathrm{a}}$ & * & $7.49 \pm 0.05^{\mathrm{a}}$ & * & $7.57 \pm 0.05^{\mathrm{a}}$ & * \\
\hline Production & 1 & $7.15 \pm 0.05^{\mathrm{a}}$ & 0.26 & $7.20 \pm 0.03^{\mathrm{a}}$ & 0.29 & $7.37 \pm 0.04^{\mathrm{a}}$ & 0.20 \\
\hline Fermentation & 3 & $6.28 \pm 0.05^{c}$ & 1.13 & $6.66 \pm 0.10^{\mathrm{a}}$ & 0.83 & $6.70 \pm 0.04^{b}$ & 0.88 \\
\hline \multirow{4}{*}{ Drying } & 5 & $6.05 \pm 0.06^{c}$ & 1.35 & $6.53 \pm 0.12^{\mathrm{a}}$ & 0.96 & $6.67 \pm 0.03^{b}$ & 0.90 \\
\hline & 10 & $5.90 \pm 0.07^{\mathrm{c}}$ & 1.51 & $5.99 \pm 0.25^{b}$ & 1.50 & $6.50 \pm 0.06^{\mathrm{b}}$ & 1.07 \\
\hline & 17 & $4.69 \pm 0.04^{\mathrm{d}}$ & 2.72 & $5.89 \pm 0.22^{\mathrm{b}}$ & 1.60 & $5.61 \pm 0.03^{c}$ & 1.97 \\
\hline & 24 & $3.89 \pm 0.09^{\mathrm{e}}$ & 3.52 & $5.47 \pm 0.26^{\mathrm{b}}$ & 2.01 & $4.68 \pm 0.06^{\mathrm{d}}$ & 2.90 \\
\hline \multirow[t]{4}{*}{ Packaging } & 52 & $0.60 \pm 0.07^{\mathrm{h}}$ & 6.81 & $2.61 \pm 0.55^{\mathrm{f}}$ & 4.88 & $0.61 \pm 0.07^{\mathrm{g}}$ & 6.96 \\
\hline & 59 & $0.38 \pm<0.01^{\mathrm{h}}$ & 7.03 & $2.28 \pm 0.51^{\mathrm{f}}$ & 5.20 & $0.40 \pm 0.02^{\mathrm{g}}$ & 7.17 \\
\hline & 66 & $0.38 \pm<0.01^{\mathrm{h}}$ & 7.03 & $1.58 \pm 0.27^{\mathrm{g}}$ & 5.90 & $0.38 \pm<0.01^{\mathrm{g}}$ & 7.19 \\
\hline & $\begin{array}{c}\text { Total } \\
\text { reduction }\end{array}$ & & 7.03 & & 5.90 & & 7.19 \\
\hline
\end{tabular}

Pathogen concentrations with different superscripts ${ }^{\mathrm{a}-\mathrm{h}}$ are statistically different than the pathogen concentration from the preceding sampling day $(P<0.05)$. Comparisons are only made within columns for individual pathogens.

enrichment results on all sampling days. Campylobacter spp. produced negative enrichment results on day 66.

In addition to achieving the average reductions in pathogen concentrations stated above, the processing parameters of fermenting and drying were able to achieve the desired reductions in $\mathrm{pH}$ and $\mathrm{a}_{\mathrm{w}}$ (Table 2). Finished duck salami achieved a final $\mathrm{pH}$ of 5.11 and a final $\mathrm{a}_{\mathrm{w}}$ of $0.81 \mathrm{pH}$ first decreased below the target of 5.3 on day 3 , after fermentation was completed, with a $\mathrm{pH}$ of 5.00. $\mathrm{pH}$ below 5.3 was maintained from day 3 to day 66 when processing was completed. aw first decreased below the target of 0.90 on day 31 , with a $\mathrm{a}_{\mathrm{w}}$ of 0.88 , and then maintained values less than 0.90 until the end of processing on day 66 .

\section{DISCUSSION}

Despite the advances in meat processing technologies and methods, the bacterial safety and sensory quality of salami products that are raw and RTE are still of concern. The use of duck in a traditionally processed salami also presents multiple additional challenges inherent to duck, especially when considering the bacterial safety of uncooked products that are RTE. Since most manufacturers of artisanal products do not utilize a thermal lethality treatment, a challenge study for a raw, RTE duck salami may be sufficient for validating the safety of the product, provided that appropriate reductions of all pathogens relevant to the product are achieved.

This experiment is one of the first demonstrating the safety of a raw, RTE salami containing duck. The necessary reductions of Salmonella spp., L. monocytogenes, and Campylobacter spp. ( $>5 \log \mathrm{CFU} / \mathrm{g}$ ) were successfully achieved in the final product. The results of this experiment also further support the utility of organic acid treatments as additional hurdles for meat processes that do not utilize thermal treatments and confirm that the validation of traditionally produced duck salami could be achieved. Nightingale et al. (33) concluded that the traditional processing steps of fermenting and drying would not be sufficient to ensure the bacterial safety of Italian salami and that a thermal processing step would be needed to prevent the presence of pathogens in the final product. They were only able to demonstrate maximum reductions of 4.5 and $<1 \log$ CFU/g of Salmonella spp. and L. monocytogenes, respectively, in traditionally processed salamis. Instead of utilizing a thermal processing step during traditional salami production, some manufacturers have begun to use organic acid treatments of raw meat prior to grinding and stuffing. McKinney et al. (31) and Rivera-Reyes et al. (35) demonstrated that 
TABLE 2. Water loss ( $n=1$ for each replication), salami diameter $(n=3), \mathrm{pH}(n=6)$, and $\mathrm{a}_{\mathrm{w}}(n=3)$ of duck salami during processing

\begin{tabular}{|c|c|c|c|c|c|c|c|}
\hline Processing step & Day & $\begin{array}{l}\text { Water loss } \\
(\%) \text { in } \\
\text { replication } 1\end{array}$ & $\begin{array}{l}\text { Water loss } \\
(\%) \text { in } \\
\text { replication } 2\end{array}$ & $\begin{array}{l}\text { Water loss } \\
(\%) \text { in } \\
\text { replication } 3\end{array}$ & $\operatorname{Diam}(\mathbf{m m})$ & $\mathrm{pH}$ & $a_{w}$ \\
\hline Inoculation & 0 & * & * & * & * & 5.67 & 0.99 \\
\hline Production & 1 & 0 & 0 & 0 & 55 & 5.53 & 0.98 \\
\hline \multirow{2}{*}{ Fermentation } & 2 & 0.25 & 1.60 & 2.27 & 55 & 5.35 & 0.96 \\
\hline & 3 & 1.37 & 3.32 & 4.06 & 55 & 5.00 & 0.96 \\
\hline \multirow{4}{*}{ Drying } & 5 & 12.41 & 13.22 & 12.83 & 53 & 4.92 & 0.96 \\
\hline & 10 & 23.42 & 23.00 & 20.49 & 50 & 4.84 & 0.95 \\
\hline & 17 & 33.53 & 31.72 & 28.43 & 47.33 & 4.92 & 0.93 \\
\hline & 24 & 41.97 & 38.14 & 32.80 & 44.67 & 4.95 & 0.91 \\
\hline Packaging (R1) & 31 & 47.31 & 42.34 & 36.33 & 43 & 5.01 & 0.88 \\
\hline \multirow{2}{*}{ Packaging (R2) } & 38 & 47.31 & 45.32 & 39.79 & 42.67 & 4.95 & 0.86 \\
\hline & 45 & 47.31 & 45.32 & 42.06 & 42.33 & 4.97 & 0.83 \\
\hline \multirow{3}{*}{ Packaging (R3) } & 52 & 47.31 & 45.32 & 44.55 & 42 & 5.10 & 0.82 \\
\hline & 59 & 47.31 & 45.32 & 44.55 & 42 & 5.05 & 0.81 \\
\hline & 66 & 47.31 & 45.32 & 44.55 & 42 & 5.12 & 0.81 \\
\hline
\end{tabular}

raw, RTE salami containing pork and raw, RTE landjäger (pork and beef), respectively, could be produced safely without the addition of thermal processing. Both experiments utilized an organic acid treatment of the meat trim after pathogen inoculation and prior to grinding, and both experiments were able to achieve adequate reductions of the pathogens relevant to each product. Specifically, >5-log reductions of Salmonella spp. and L. monocytogenes were achieved in pork salami, and >5-log reductions of Escherichia coli O157:H7, Salmonella spp., and L. monocytogenes were achieved in landjäger. These results demonstrated that traditional meat processing techniques were adequate to ensure bacterial safety when organic acid treatments on meat surfaces were added to the process. In this experiment, a $2.5 \%$ Beefxide antimicrobial treatment was used to treat raw duck and pork. Although the reductions of each pathogen directly due to the antimicrobial treatment were not significant, the lasting effect of the acid treatment potentially causes injury to the pathogens, making the cells more susceptible to subsequent processing hurdles. Additionally, there was an increase in Campylobacter spp. from day 31 to 38 that was associated with vacuum packaging; however, the increase was less than $1 \log \mathrm{CFU} / \mathrm{g}$, and increases of less than $1 \log \mathrm{CFU} / \mathrm{g}$ are not considered to be true microbial growth.

The decrease in both $\mathrm{pH}$ and $\mathrm{a}_{\mathrm{w}}$ is influenced by multiple factors inherent to the product and the processing environment. Those values could vary at the same time across multiple replications or batches. Because of that variation, fermentation time, drying time, or water loss cannot be used as critical parameters instead of $\mathrm{pH}$ and $\mathrm{a}_{\mathrm{w}}$. The target parameters of a final $\mathrm{pH}$ of less than 5.3 and a final $\mathrm{a}_{\mathrm{w}}$ of less than 0.90 were used as a baseline; however, the critical values of these parameters for product safety were lower than the target parameters. In duck salami, the critical parameters for a final $\mathrm{pH}$ of less than 5.2 and a final $\mathrm{a}_{\mathrm{w}}$ of less than 0.87 must be followed for the reduction of Salmonella spp., L. monocytogenes, and Campylobacter spp. to be achieved. $\mathrm{pH}$ measurements of less than 5.2 were first achieved at the end of fermentation (day 3 ) and were maintained until the end of processing on day 66 (Table 2). The final $\mathrm{pH}$ of 5.12 meets the critical parameter of less than $\mathrm{pH}$ 5.2. Additionally, the starter culture used in this experiment produced bacteriocins and pediocins. Although no controls were conducted using a starter culture that did not produce bacteriocins or pediocins, the product should not be produced without a starter culture that is able to produce those antilisterial compounds. There were some fluctuations in $\mathrm{pH}$ throughout processing, but $\mathrm{pH}$ never increased above 5.2 after fermentation was completed. $a_{w}$ first dropped below the critical parameter of 0.87 on day 38 , with a $a_{w}$ of 0.86 (Table 2). It did not increase at any point during processing and reached a final $a_{w}$ of 0.81 on day 66 .

\section{CONCLUSIONS}

These data confirm the microbiological safety of duck salami and can be used as scientifically valid evidence in a HACCP system when meat processors are producing a raw, 
RTE duck salami. In addition to utilizing good manufacturing practices, processors must maintain the following critical parameters. Duck meat and pork must be treated with a $2.5 \%$ Beefxide solution prior to salami production. The duck salami must be formulated with $2.5 \%$ salt and $0.24 \%$ cure \#2 (92.75\% salt, $6.25 \%$ sodium nitrite, and $1 \%$ sodium nitrate), fermented to a $\mathrm{pH}$ of less than 5.2, and dried to a aw of less than 0.87 . The product must contain at least 150 ppm of in-going sodium nitrite and $24 \mathrm{ppm}$ of in-going sodium nitrate but remain within regulatory requirements for comminuted meat and poultry products. Lastly, the finished duck salami must be stored under vacuum at $\sim 23^{\circ} \mathrm{C}$ prior to consumption. Testing raw duck and pork for Salmonella spp. and Campylobacter spp. can be utilized to eliminate the need for vacuum-packaging storage prior to consumption.

\section{ACKNOWLEDGMENTS}

The researchers would like to thank Dr. Jasna Kovac for her valuable assistance while working with Campylobacter cultures, as well as Charles Connolly and Kaylee Kishbaugh for their help during salami manufacturing. This work was supported by Hatch project number PEN04696 and approved under IBC number 47758.

\section{REFERENCES}

1. Adzitey, F., N. Huda, and G. R. Rahmat Ali. 2012. Prevalence and antibiotic resistance of Campylobacter, Salmonella, and L. monocytogenes in ducks: a review. Foodborne Pathog. Dis. 9:498-505.

2. Angelidis, A. S., and K. Koutsoumanis. 2006. Prevalence and concentration of Listeria monocytogenes in sliced ready-to-eat meat products in the Hellenic retail market. J. Food Prot. 69:938-942.

3. Arnaud, E., S. J. Santchurn, and A. Collignan. 2014. Fermented poultry sausages, p. 331338. In F. Toldrá, Y. H. Hui, I. Astiasarán, J. G. Sebranek, and R. Talon (ed.), Handbook of fermented meat and poultry. John Wiley \& Sons, Inc., Chichester, UK.

4. Beales, N. 2004. Adaptation of microorganisms to cold temperatures, weak acid preservatives, low $\mathrm{pH}$, and osmotic stress: a review. Comp. Rev. Food Sci.

5. Benedict, R. C., F. J. Schultz, and S. B. Jones. 1990. Attachment and removal of Salmonella spp. on meat and poultry tissues. J. Food Saf. 11:135-148.

6. Blackman, I. C., and J. F. Frank. 1996. Growth of Listeria monocytogenes as a biofilm on various food-processing surfaces. J. Food Prot. 59:827-831.

7. Centers for Disease Control and Prevention. 2018. National Outbreak Reporting System (NORS). Available from: https://wwwn.cdc gov/norsdashboard/. Accessed 16 May 2019.

8. Centers for Disease Control and Prevention. 2019. Salmonella. Available from: https:// www.cdc.gov/salmonella/index.html. Accessed 1 May 2019.

9. Centers for Disease Control and Prevention. 2019. Campylobacter (campylobacteriosis). Available from: https://www.cdc.gov/ campylobacter/index.html. Accessed 1 May 2019.

10. Centers for Disease Control and Prevention. 2019. Listeria (listeriosis). Available from: https://www.cdc.gov/listeria/faq.html. Accessed 1 May 2019.

11. Chaturongakul, S., S. Raengpradub, M. Wiedmann, and K. J. Boor. 2008. Modulation of stress and virulence in Listeria monocytogenes. Trends Microbiol. 16:388-396.
12. Draper, A. D., C. N. Morton, J. N. Heath, J. A. Lim, A. I. Schiek, S. Davis, V. L. Krause, and P. G. Markey. 2017. An outbreak of salmonellosis associated with duck prosciutto at a Northern Territory restaurant. Commun. Dis. Intell. Q. Rep. 41:E16-E20.

13. Endrikat, S., D. Gallagher, R. Pouillot, H. H. Quesenberry, D. LaBarre, C. M. Schroeder, and J. Kause. 2010. A comparative risk assessment for Listeria monocytogenes in prepackaged versus retail-sliced deli meat. J. Food Prot. 73:612-619.

14. Ferreira, V., M. Wiedmann, P. Teixeira, and M. J. Stasiewicz. 2014. Listeria monocytogenes persistence in food-associated environments: epidemiology, strain characteristics, and implications for public health. J. Food Prot. 77:150-170.

15. Foong, S. C. C., and J. S. Dickson. 2004. Attachment of Listeria monocytogenes on ready-to-eat meats. J. Food Prot. 67:456-462.

16. Gandhi, M., and M. L. Chikindas. 2007. Listeria: a foodborne pathogen that knows how to survive. Int. J. Food Microbiol. 113:1-15.

17. Gianfranceschi, M., A. Gattuso, A. Fiore, M. C. D’Ottavio, M. Casale, A. Palumbo, and P. Aureli. 2006. Survival of Listeria monocytogenes in uncooked Italian dry sausage (salami). J. Food Prot. 69:1533-1538.

18. Goh, S. G., A.-H. Leili, C. H. Kuan, Y. Y Loo, Y. L. Lye, W. S. Chang, P. Soopna, M. S. Najwa, J. Y. H. Tang, R. Yaya, M. Nishibuchi, Y. Nakaguchi, and R. Son. 2014. Transmission of Listeria monocytogenes from raw chicken meat to cooked chicken meat through cutting boards. Food Control 37:51-55.

19. Gombas, D. E., Y. Chen, R. S. Clavero, and V. N. Scott. 2003. Survey of Listeria monocytogenes in ready-to-eat foods. J. Food Prot. 66:559-569.

20. Hierro, E., M. Fernández, L. de la Hoz, and J. A. Ordóñez. 2014. Mediterranean products, 301-312. In F. Toldrá, Y. H. Hui, I. Astiasarán, J. G. Sebranek, and R. Talon (ed.), Handbook of fermented meat and poultry. John Wiley \& Sons, Ltd., Chichester, UK.
21. Hill, C., P. D. Cotter, R. D. Sleator, and C. G. M. Gahan. 2002. Bacterial stress response in Listeria monocytogenes: jumping the hurdles imposed by minimal processing. Int. Dairy J. 12:273-283.

22. Ingham, S. C., D. R. Buege, B. K. Dropp, and J. A. Losinski. 2004. Survival of Listeria monocytogenes during storage of ready-toeat meat products processed by drying, fermentation, and/or smoking. J. Food Prot. 67:2698-2702.

23. Khan, I., C. N. Tango, S. Miskeen, B. H. Lee, and D.-H. Oh. 2017. Hurdle technology: a novel approach for enhanced food quality and safety-a review. Food Control 73:1426-1444.

24. Landrum, M. A., N. A. Cox, D. E. Cosby, M. E. Berrang, and S. M. Russell. 2016. Treatment with a low $\mathrm{pH}$ processing aid to reduce Campylobacter counts on broiler parts. Poult. Sci. 96:1028-1031.

25. Leistner, L. 2000. Basic aspects of food preservation by hurdle technology. Int. J. Food Microbiol. 55:181-186.

26. Leistner, L., and L. G. M. Gorris. 1995. Food preservation by hurdle technology. Trends Food Sci. Technol. 6:41-46.

27. Leroy, F., J. Verluyten, and L. De Vuyst. 2006. Functional meat starter cultures for improved sausage fermentation. Int. J. Food Microbiol. 106:270-285.

28. Li, J., J. Feng, L. Ma, C. de la Fuente Núñez, G. Gölz, and X. Lu. 2017. Effects of meat juice on biofilm formation of Campylobacter and Salmonella. Int. J. Food Microbiol. 253:20-28.

29. Maddock, R. 2014. U.S. products-dry sausage, p. 293-299. In F. Toldrá, Y. H. Hui, I Astiasarán, J. G. Sebranek, and R. Talon (ed.), Handbook of fermented meat and poultry. John Wiley \& Sons, Ltd., Chichester, UK.

30. McCrea, B. A., K. H. Tonooka, C. VanWorth, C. L. Boggs, E. R. Atwill, and J. S. Schrader. 2006. Prevalence of Campylobacter and Salmonella species on farm, after transport, and at processing in specialty market poultry. Poult. Sci. 85:136-143. 
31. McKinney, S., N. Ostiguy, C. Cutter, and J. Campbell. 2019. Pathogen reductions during traditional fermentation and drying of pork salamis. Food Prot. Trends 39:18-27.

32. Nguyen, V. T., M. S. Turner, and G. A. Dykes. 2010. Effect of temperature and contact time on Campylobacter jejuni attachment to, and probability of detachment from, stainless steel. J. Food Prot. 73:832-838.

33. Nightingale, K. K., H. Thippareddi, R. K. Phebus, J. L. Marsden, and A. L. Nutsch. 2006. Validation of a traditional Italian-style salami manufacturing process for control of Salmonella and Listeria monocytogenes. J. Food Prot. 69:794-800.

34. Ritz, M., M. J. Nauta, P. F. M. Teunis, F. van Leusden, M. Federighi, and A. H. Havelaar. 2007. Modelling of Campylobacter survival in frozen chicken meat. J. Appl. Microbiol. 103:594-600.

35. Rivera-Reyes, M., J. A. Campbell, and C. N. Cutter. 2017. Pathogen reductions associated with traditional processing of landjäger. Food Control 73:768-774.

36. Rust, R. E. 2014. U.S. products-semidry sausage, p. 281-285. In F. Toldrá, Y. H. Hui, I. Astiasarán, J. G. Sebranek, and R. Talon (ed.), Handbook of fermented meat and poultry. John Wiley \& Sons, Ltd., Chichester, UK.
37. Shen, C., L. Lemonakis, X. Etienne, K. Li, W. Jiang, and J. M. Adler. 2019. Evaluation of commercial antimicrobials against stressadapted Campylobacter jejuni on broiler wings by using immersion and electrostatic spray and an economic feasibility analysis. Food Control 103:161-166.

38. Skarp, C. P. A., M.-L. Hänninen, and H. I. K. Rautelin. 2016. Campylobacteriosis: the role of poultry meat. Clin. Microbiol. Infect. 22:103-109.

39. U.S. Department of Agriculture, Food Safety and Inspection Service. 2017. FSIS Salmonella compliance guidelines for small and very small meat and poultry establishments that produce ready-toeat (RTE) products. U.S. Department of Agriculture, Washington, D.C. Available from: https://www.fsis.usda.gov/ sites/default/files/import/SalmonellaCompliance-Guideline-SVSP-RTEAppendix-A.pdf. Accessed 1 May 2019.

40. U.S. Department of Agriculture, Food Safety and Inspection Service. 2019. 9 CFR 417. Title 9-Animals and Animal Products, part 417-Hazard analysis critical control point (HACCP) systems. U.S. Department of Agriculture, Washington, D.C.
41. U.S. Department of Agriculture, Food Safety and Inspection Service. 2014. Summary of Listeria monocytogenes compliance guideline for small and very small meat and poultry plants that produce ready-to-eat products. U.S. Department of Agriculture, Washington, D.C. https://meathaccp.wisc.edu/assets/ LM_Guidelines_for_SVSP_Ready_to_Eat_ Products.pdf. Accessed 1 May 2019.

42. Wei, B., and M. Kang. 2018. In vitro activity of fosfomycin against Campylobacter isolates from poultry and wild birds. T. Webster, editor. PLoS One 13:e0200853.

43. Yogasundram, K., S. M. Shane, and K. S. Harrington. 1989. Prevalence of Campylobacter jejuni in selected domestic and wild birds in Louisiana. Avian Dis. 33:664-667.

44. Zhu, M., M. Du, J. Cordray, and D. U. Ahn. 2005. Control of Listeria monocytogenes contamination in ready-to-eat meat products. Comp. Rev. Food Sci. Food Safety 4:34-42. 